\title{
Enhancement of radiosensitivity by topoisomerase II inhibitor, amrubicin and amrubicinol, in human lung adenocarcinoma A549 cells and kinetics of apoptosis and necrosis induction
}

\author{
SACHIKO HAYASHI $^{1}$, MASANORI HATASHITA ${ }^{4}$, HIDEKI MATSUMOTO ${ }^{1}$, \\ HIROKI SHIOURA $^{2}$, RYUHEI KITAI ${ }^{3}$ and EIICHI KANO ${ }^{1}$
}

\author{
Departments of ${ }^{1}$ Experimental Radiology and Health Physics, ${ }^{2}$ Radiology, and ${ }^{3}$ Neurosurgery, \\ University of Fukui, Matsuoka, Fukui 910-1193; ${ }^{4}$ The Wakasawan Energy Research Center, \\ Research and Development Department, Tsuruga 914-0192, Japan
}

Received June 5, 2006; Accepted August 2, 2006

\begin{abstract}
The effects of amrubicin (AMR) and its active metabolite, amrubicinol (AMROH), on the sensitivity of human lung adenocarcinoma A549 cells to ionizing radiation were investigated in vitro. Further, the kinetics of apoptosis and necrosis induction were also analyzed. The cytocidal effects of X-ray irradiation on A549 cells resulted in a low level of radiosensitivity with a $\mathrm{D}_{0}$ value of $12 \mathrm{~Gy}$. The slopes of the survival curves in the exponential phase were plotted on semilogarithmic paper for radiation combined with AMR $(2.5 \mu \mathrm{g} / \mathrm{ml})$ and AMROH $(0.02 \mu \mathrm{g} / \mathrm{ml})$ treatment, and were shown to be approximately parallel to treatment with irradiation alone. The initial shoulder-shape portion of the survival curve for radiation alone, indicating the repair of sublethal damage, was reduced as compared to that for sequential combined treatment with AMR or AMROH. Sequential treatments with AMR or AMROH prior to ionizing radiation resulted in an additive radio-enhancement effect that reduced not only survival, but also the shoulder width. Fractionated irradiation with 2 Gy per fraction of A549 cells was carried out in vitro similar to that commonly performed in clinical radiotherapy and the radio-resistance of the cells was shown to be inhibited by AMR and AMROH. Similar to AMR and AMROH, adriamycin and etoposide (VP-16) are DNA topoisomerase II inhibitors. The effects of these 4 agents on cells that received $\mathrm{X}$-ray irradiation were compared and all of the agents exhibited comparable radio-enhancement effects. The induction of apoptosis was investigated at 48 and $72 \mathrm{~h}$ after administration of $\mathrm{AMROH}$, radiation or combined treatment, and apoptosis
\end{abstract}

Correspondence to: Dr Sachiko Hayashi, Department of Experimental Radiology, Faculty of Medical Science, University of Fukui, Matsuoka, Fukui 910-1193, Japan

E-mail: hayashis@fmsrsa.fukui-med.ac.jp

Key words: amrubicin, human lung adenocarcinoma A549 cells, enhancement, X-rays, radiosensitivity, apoptosis, necrosis, topoisomerase II was not significantly induced after any of the treatments. We also examined the induction of necrosis, and found that the incidence of necrosis following combined treatment was approximately 2 times higher than that with either of the single treatments.

\section{Introduction}

Amrubicin hydrochloride (AMR), an anthracycline derivative $(1,2)$, exhibits antitumor effects by inhibiting topoisomerase II activity and suppressing DNA synthesis $(3,4)$. AMR is metabolized to amrubicinol (AMROH) in vivo and has antitumor activity against human non-small cell lung, small cell lung, and superficial bladder cancer, with anticancer effects that range from 10-100 times greater than AMR (5-7). There appears to be a unique correlation between the sensitivity to ionizing radiation and to topoisomerase II inhibitors, which stabilize the cleavable complex between the enzymes and DNA (8).

Previous reports have clarified that human lung adenocarcinoma A549 cells are radio- or thermo-resistant (9-13) and have a mutated $K$-ras gene $(14,15)$ and wild-type $p 53$ gene $(15,16)$. When DNA is damaged, wild-type p53 protein is activated by a phosphorylation signaling pathway, after which it exhibits antitumor effects by inducing either apoptosis or $\mathrm{G}_{1}$ arrest (17-22). In several studies of cultured cells, it has also been found that cells with wild-type $p 53$ are more radiosensitive than cells with mutant p53 (23-26). The ras gene was one of the first oncogenes discovered and is known to be involved in cellular proliferation and differentiation (27-29). We previously reported that the surviving fractions (SFs) prior to treatment with AMR or AMROH before exposure to $44^{\circ} \mathrm{C}$ hyperthermia using the A549 cell line showed an additive thermo-enhancement effect due to inhibition of the repair of sublethal thermal damage (SLTDR) exhibited during the early stages of hyperthermia (13). We also reported that AMR and AMROH did not elicit cell phase responses, irrespective of the concentration of chemicals, and that the cytotoxicity of pretreatment with AMROH during hyperthermia against A549 cells with wild-type $p 53$ was due to increased necrosis, not apoptosis (13). 
In the present study, we analyzed the effects of modification of AMR and AMROH by X-ray irradiation at the kinetic and molecular levels on the sensitivity of A549 cells with the above-mentioned genetic backgrounds. The SFs of cells treated with X-rays alone showed radio-tolerance due to the repair of sublethal damage (SLDR), which was demonstrated by a so-called shoulder-shaped portion in the initial slope of the survival curve plotted on plotting paper (30). In this study, we examined the effects of radio-enhancement by AMR and AMROH on the sensitivity of A549 cells to X-rays and compared them with the effects of 2 other DNA topoisomerase II inhibitors, ADM and VP-16. Clinical radiotherapy is generally treated by small-dose fractionated irradiation. In fundamental studies of fractionated irradiation, variations of surviving fractions by SLDR and cellular redistribution following the second irradiation with various interval periods between the 2 exposures have been found $(31,32)$. It was also reported that the response of A549 cells in vitro to fractionated irradiation with interval periods of 8-10 h between fractionated doses is required to obtain maximum SLDR (33).

In the present experiments, treatments of 2 Gy were performed on 4 fractions with a $24 \mathrm{~h}$ interval to elucidate the effects of clinical conventional fractionated irradiation. We also analyzed the sensitivity of A549 cells treated with AMR or AMROH for $3 \mathrm{~h}$ prior to X-ray irradiation by colonial SFs. As a result, the survival curves of cells treated with fractionated X-ray irradiation following administration with AMR and AMROH demonstrated inhibition of the amount of SLDR by both chemicals, which demonstrated synergistic radioenhancement effects that were significant in comparison with single fractionated irradiation.

DNA damaging agents such as topoisomerase II inhibitors, e.g. etoposide (VP-16) and doxorubicin (adriamycin), lead to double-strand breaks and cell death via apoptosis (34). A previous study of a topoisomerase II inhibitor showed that it mediated DNA damage by adriamycin and other related antitumor drugs (35) and modified damage caused by X-ray irradiation damage $(36,37)$. In the present study, we investigated the induction of apoptosis $(38,39)$ and necrosis $(40,41)$ in A549 cells with the wild-type $p 53$ gene and mutant K-ras, which were treated with $\mathrm{AMROH}$ for $4 \mathrm{~h}$ following X-ray irradiation of $6 \mathrm{~Gy}$.

\section{Materials and methods}

Cells and culture medium. The A549 cell line, from a human lung adenocarcinoma $(42,43)$, was cultured in Eagle's minimum essential medium (Nissui Pharmaceutical, Tokyo, Japan) containing NCTC-135 (Gibco Laboratories, Grand Island, NY, USA), lactalbumin hydrolysate solution (Difco Laboratories, Detroit, USA), and 15\% newborn calf serum (Gibco) (hereafter referred to as MLN-15).

Chemicals, X-ray irradiation and treatments. AMR and AMROH (Sumitomo Pharmaceuticals Co. Ltd., Osaka, Japan) were dissolved separately in culture medium to an appropriate final concentration prior to treatment of the cells. Adhered A549 cells in flasks were treated with AMR or AMROH by replacement of MLN-15 with $6 \mathrm{ml}$ of the agent for various time periods. After exposure to AMR or AMROH, the adhered cells were chased, then gently rinsed twice and re-fed with $6 \mathrm{ml}$ of MLN-15. Thereafter, the treated flasks were incubated stationary in a $5 \% \mathrm{CO}_{2}$ incubator at $37^{\circ} \mathrm{C}$ (BNA-111B; Tabai Espec. Co. Ltd., Osaka, Japan) until visible colony formation. Irradiation was carried out using High Technical System X-ray apparatus (HW-150; Hitex Co. Ltd., Tokyo, Japan), with the following settings: $130 \mathrm{kVp}, 5 \mathrm{~mA}, 0.5-\mathrm{mm}$ aluminum filter, dose rate of $1.0 \mathrm{~Gy} / \mathrm{min}$.

For combined treatment, chemotherapy and radiotherapy were performed sequentially. Cells treated with AMR or AMROH for $3 \mathrm{~h}$, were rinsed twice with culture medium containing 3\% serum, then placed in MLN-15 and subjected to X-ray irradiation. Kinetics assessment of the sensitivity of A549 cells to chemicals and radiation was performed using a colony formation method and corrected based on the plating efficiency of the control (i.e. 80-90\%). The average colony multiplicity was $<1.1$. The $\mathrm{D}_{0}$ value, adopted as the criterion of cellular radiosensitivity or chemosensitivity, represented the doses required to reduce survival by $1 / \mathrm{e}$ in the exponentially regressing portion of the survival curves, i.e. the linear portions of the doses (or treatment period) - surviving fractions curve plotted on semilogarithmic section paper. Fractionated radiotherapy was carried out for 1-4 fractions at $2 \mathrm{~Gy}$ for $24 \mathrm{~h}$ intervals at $37^{\circ} \mathrm{C}$.

Analysis of apoptosis and necrosis. The induction of apoptosis was analyzed at 48 and $72 \mathrm{~h}$ after treatment with $0.02 \mu \mathrm{g} / \mathrm{ml}$ AMROH for $4 \mathrm{~h}, \mathrm{X}$-ray irradiation at $6 \mathrm{~Gy}$, and a combination of both. Trypsinized cells were placed in MLN-15 to stop trypsinization, then rinsed with PBS(-), fixed overnight in $1 \%$ glutaraldehyde (Nakalai Tesque, Kyoto, Japan), and placed in PBS(-). For observation, cells were stained with $0.2 \mathrm{mM}$ Höchst 33342; Bisbenzimide H33342 Fluorochrome, Trihydrochloride (Calbiochem, Merck KGoA, Darmstadt, Germany) and analyzed under a fluorescence microscope (Nikon Eclipse E600, Nikon Co. Ltd., Tokyo, Japan). A total of 1000 cells were counted and the percentage of typical apoptotic cells was calculated. The induction of necrosis was also determined after the treatments described above. After double-staining the cells with acridine orange (Sigma-Aldrich Co. St. Louis, USA) and ethidium bromide (Nacalai Tesque Inc.) $(\mathrm{AO} / \mathrm{EB})(44)$, they were observed in real-time under a fluorescence microscope and the percentage of rubinus necrotic cells was calculated.

\section{Results}

Survival of A549 cells following X-ray irradiation. As for the radiosensitivity of $\mathrm{A} 549$ cells, the $\mathrm{D}_{0}$ value, which was the reciprocal of the slope of the survival curve in the exponential phase, was 2.0 Gy following irradiation. As in the case of Elkind recovery associated with low-dose radiotherapy, the SLDR, which is seen as a curved shoulder, was identified during the early stages following irradiation. The $\mathrm{D}_{\mathrm{q}}$ value reflecting cellular capacity for SLDR, was 1.7 Gy as shown in Figs. 1 and 2.

Effects of $A M R$ and AMROH with X-ray irradiation. Using A549 cells, the radio-enhancement effects of AMR and AMROH were investigated based on the survival curves drawn 


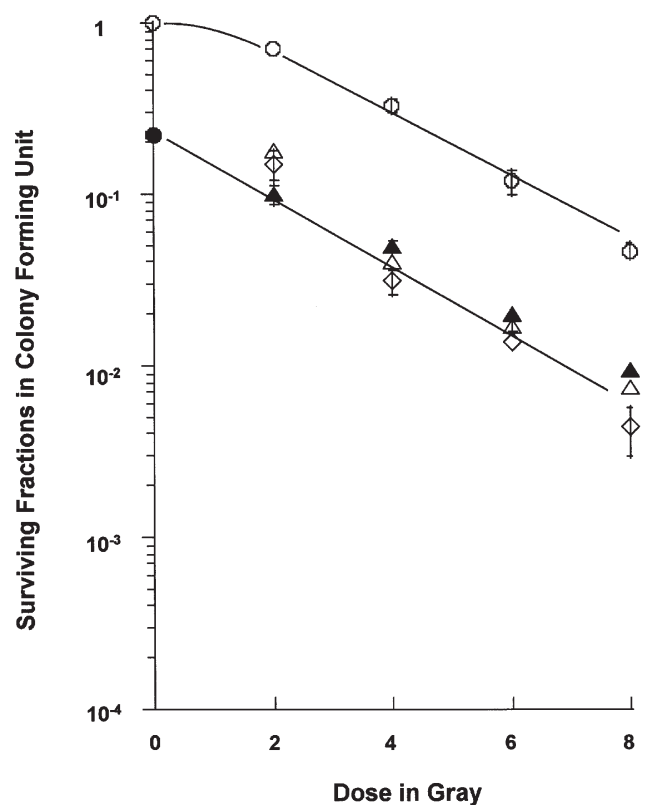

Figure 1. Radio-enhancement effects of AMR $(2.5 \mu \mathrm{g} / \mathrm{ml})$ on A549 cells. Ordinate: log surviving fractions (SFs) in colony forming units. Abscissa: $\mathrm{X}$-ray irradiation doses are shown in gray. $\circ, \mathrm{SFs}$ of cells that received irradiation alone. $\diamond, \mathrm{SFs}$ of cells following combined simultaneous treatment with AMR and irradiation. $\triangle$, SFs of cells treated with graded doses of X-rays followed by AMR exposure for $3 \mathrm{~h}$. $\mathbf{\Delta}, \mathrm{SFs}$ of cells treated with graded doses of X-rays following pre-treatment with AMR for $3 \mathrm{~h}$. • on ordinate, SFs of cells treated with AMR alone for $3 \mathrm{~h}$. Symbols with vertical bars represent the means with standard errors obtained from 3 independent experiments. Symbols without a bar represent the standard error within the symbols.

following irradiation and $\mathrm{AMROH}$ combination therapy as shown in Figs. 1 and 2. The survival curve of the cells that received irradiation alone elicited a shoulder, indicating the repair of SLD, whereas the curve for those cells following sequential combined treatment with AMR or AMROH was reduced. In other words, SLDR associated with low doses of radiation was blocked by AMR or AMROH. Further, the survival curve slopes in the exponential phase for irradiation alone and combination therapy with AMR or AMROH were parallel, i.e. administration of AMR or AMROH prior to irradiation resulted in additive radio-enhancement effects. The combined treatment dose to accomplish cytocidal effects as well as irradiation alone was reduced by one-third. Also the radio-enhancement effects of 4 topoisomerase II inhibitors in isotoxic doses, ADM $(0.02 \mu \mathrm{g} / \mathrm{ml}), \mathrm{VP}-16(2.0 \mu \mathrm{g} / \mathrm{ml})$, AMR $(2.5 \mu \mathrm{g} / \mathrm{ml})$, and AMROH $(0.02 \mu \mathrm{g} / \mathrm{ml})$ with X-ray irradiation at 2 or 8 Gy were compared with the results shown in Table I. The effects of the 4 different chemicals as estimated by their $D_{0}$ values were comparable to the markedly enhanced effects of X-ray irradiation.

Fractionated X-ray irradiation with AMR and AMROH. Fractionated irradiation of $2 \mathrm{~Gy}$ per fraction was carried out 4 times with $24 \mathrm{~h}$ intervals for a total dose of 8 Gy using A549 cells, as shown in Figs. 3 and 4. Although the survival curve of irradiation alone exhibited radio-resistance due to SLDR, the shoulder-shaped portion of the curve was inhibited by simultaneous or sequential combined treatments with AMR or AMROH for $3 \mathrm{~h}$ prior to irradiation. Further, the survival

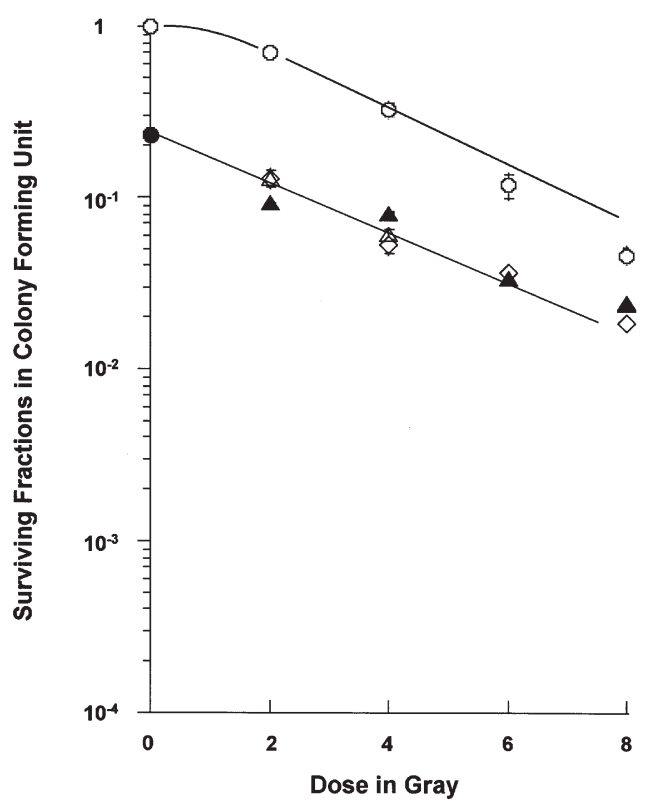

Figure 2. Radio-enhancement effects of AMROH $(0.02 \mu \mathrm{g} / \mathrm{ml})$ on A549 cells. Ordinate: $\log$ surviving fractions (SFs) in colony forming units. Abscissa: X-ray irradiation doses are shown in gray. $\bullet$, SFs of cells that received irradiation alone. $\diamond$, SFs of cells following combined simultaneous treatment with AMROH and irradiation. $\triangle$, SFs of cells treated with graded doses of irradiation followed by AMROH exposure for $3 \mathrm{~h}$. $\mathbf{\Delta}$, SFs of cells treated with graded doses of X-rays following pre-treatment with AMROH for $3 \mathrm{~h}$. - on ordinate, SFs of cells treated with AMROH alone for $3 \mathrm{~h}$. Symbols with vertical bars represent the means with standard errors obtained from 3 independent experiments. Symbols without a bar represent the standard error within the symbols.

Table I. Comparison of radio-enhancement by four topoisomerase II inhibitors.

\begin{tabular}{lcc}
\hline Chemicals & $\begin{array}{c}\text { Chemotherapy } \\
\text { X-ray irradiation }\left(\mathrm{D}_{0}\right)\end{array}$ & $\begin{array}{c}\text { Enhancement } \\
\text { ratio }\end{array}$ \\
\hline- & 2.35 & 1.00 \\
AMR & 1.70 & 1.38 \\
AMROH & 1.50 & 1.57 \\
ADM & 1.60 & 1.47 \\
VP-16 & 1.65 & 1.42 \\
\hline
\end{tabular}

The radio-enhancement effects of radiotherapy with the 4 DNA topoisomerase II inhibitors, AMR, AMROH, ADM and VP-16, were compared by $\mathrm{D}_{0}$ value. A549 cells were treated with each agent at an isotoxic dose (AMR, $2.5 \mu \mathrm{g} / \mathrm{ml}$; AMROH, $0.02 \mu \mathrm{g} / \mathrm{ml}$; ADM, $0.02 \mu \mathrm{g} / \mathrm{ml}$; VP-16, $2.0 \mu \mathrm{g} / \mathrm{ml}$ ) for $3 \mathrm{~h}$, followed by irradiation in the combined treatment protocol, respectively.

curve obtained the same slope with continuous irradiation. The surviving fractions following $8 \mathrm{~Gy}$ of irradiation showed the following results: single fractionated irradiation, 0.19; single continued irradiation, 0.047; irradiation combined with AMR, 0.0093; and irradiation combined with AMROH, 0.0068 (Figs. 3 and 4). Both AMR and AMROH inhibited SLDR of the cells following continued irradiation, and fractionated 


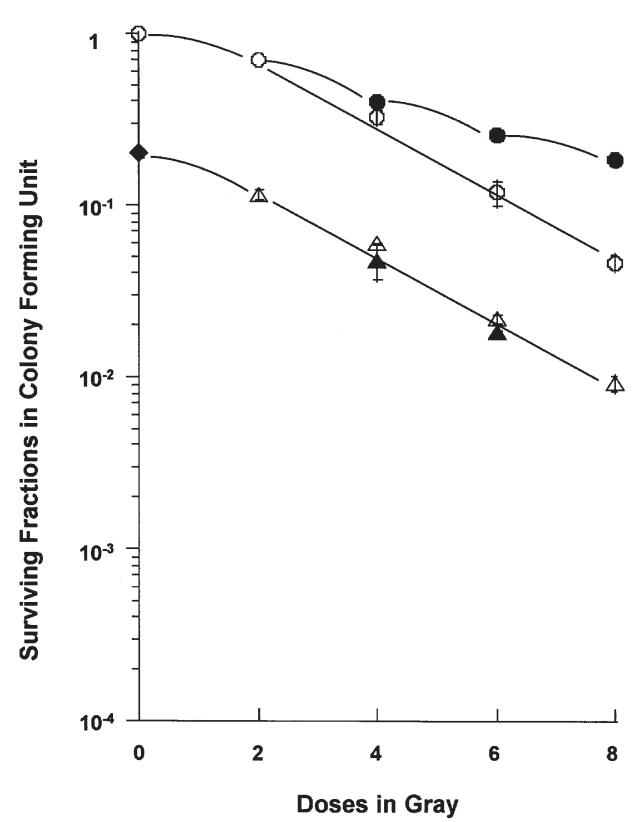

Figure 3. Fractionated X-ray irradiation with AMR $(2.5 \mu \mathrm{g} / \mathrm{ml})$ on A549 cells. Ordinate: $\log$ surviving fractions (SFs) in colony forming units. Abscissa: X-ray irradiation doses are shown in gray. $\bullet, \mathrm{SFs}$ of cells that received irradiation alone. $\bullet$ SFs of cells following simple fractionated irradiation of 2 Gy per fraction with 24-h intervals up to $8 \mathrm{~Gy} . \triangle$, SFs of cells treated with graded doses of X-rays following pre-treatment with AMR for $3 \mathrm{~h}$. $\mathbf{\Lambda}, \mathrm{SFs}$ of cells after fractionated irradiation of $2 \mathrm{~Gy}$ per fraction with 24-h intervals following pre-treatment with AMR for $3 \mathrm{~h}$. $\bullet$ on ordinate, SFs of cells treated with AMR alone for $3 \mathrm{~h}$. Symbols with vertical bars represent the means with standard errors obtained from 3 independent experiments. Symbols without a bar represent the standard error within the symbols.

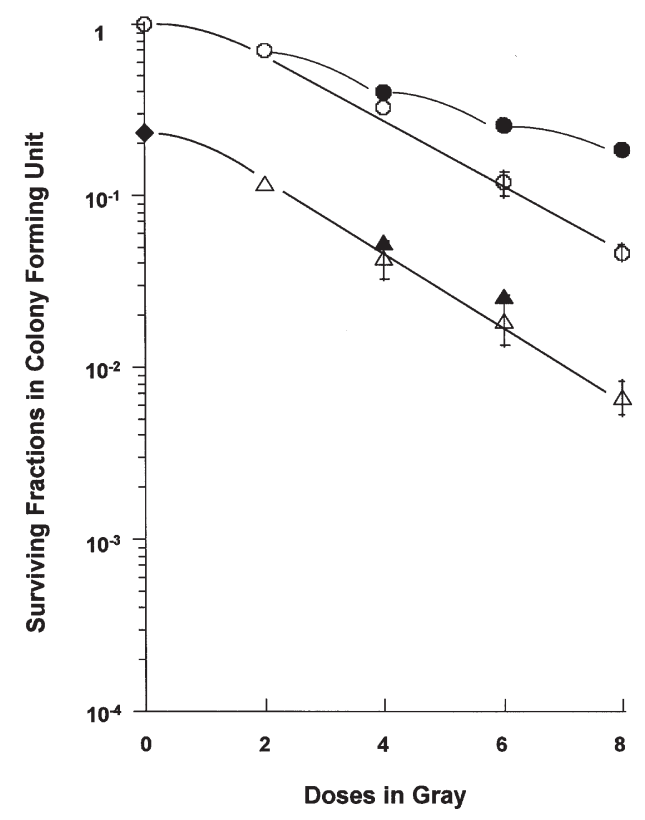

Figure 4. Fractionated X-ray irradiation with AMROH $(0.02 \mu \mathrm{g} / \mathrm{ml})$ on A549 cells. Ordinate: $\log$ surviving fractions (SFs) in colony forming units. Abscissa: $\mathrm{X}$-ray irradiation doses are shown in gray. $\bullet$, the SFs of cells that received irradiation alone. $\bullet$, SFs of cells following simple fractionated irradiation of 2 Gy per fraction with 24-h intervals up to $8 \mathrm{~Gy} . \Delta$, SFs of cells treated with graded doses of X-rays following pre-treatment with AMROH for $3 \mathrm{~h}$. $\mathbf{\Lambda}, \mathrm{SFs}$ of cells after fractionated irradiation of $2 \mathrm{~Gy}$ per fraction with 24-h intervals following pre-treatment with AMROH for $3 \mathrm{~h}$. on ordinate, SFs of cells treated with AMROH alone for $3 \mathrm{~h}$. Symbols with vertical bars represent the means with standard errors obtained from 3 independent experiments. Symbols without a bar represent the standard error within the symbols.

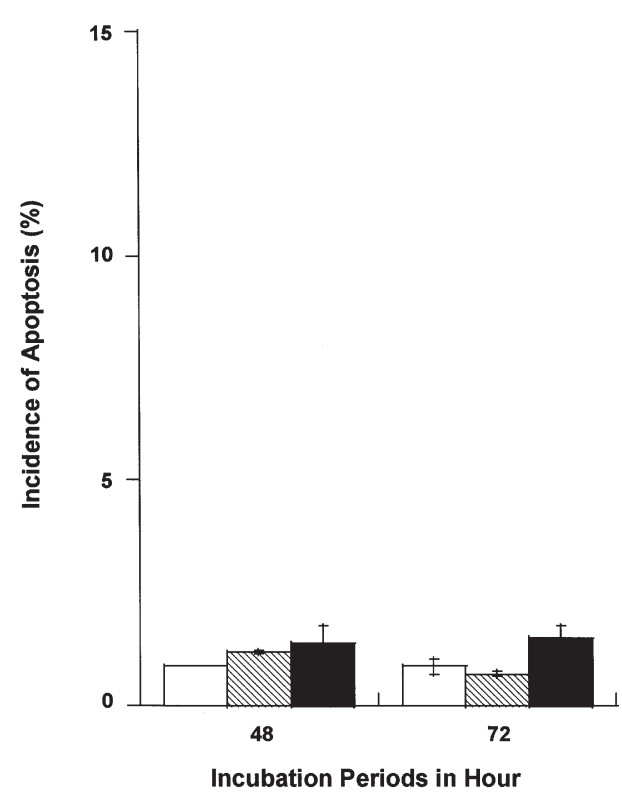

Figure 5. Kinetics of apoptosis induction after 48 and $72 \mathrm{~h}$ of incubation following exposure to AMROH, X-ray irradiation and a combination of both. At the indicated times, A549 cells were stained with Höchst 33342 and observed under a fluorescence microscope. Cells with DNA fragmented nuclei and typical morphological features of apoptosis were counted as apoptotic cells. Ordinate: ratio of apoptosis for total cells. Abscissa: hours of incubation at $37^{\circ} \mathrm{C}$ following treatment. Columns represent $\mathrm{AMROH}(0.02 \mu \mathrm{g} / \mathrm{ml})$ for $4 \mathrm{~h}$, irradiation at $6 \mathrm{~Gy}$, and combined treatment in order from the left. The incidence of apoptosis following treatment with $\mathrm{AMROH}$ or irradiation alone was slightly induced after 48 and $72 \mathrm{~h}$. With the combined treatment, the frequency of apoptosis did not increase significantly.

irradiation at 8 Gy combined with AMR or AMROH had estimated cytocidal effects in a range of 20-28 times greater in comparison with single fractionated irradiation at the same dose.

Effects on apoptosis induction. The radio-enhancement effects of AMROH on A549 cells were investigated based on the induction of apoptosis, as shown in Fig. 5. Following exposure to AMROH for $4 \mathrm{~h}, \mathrm{X}$-ray irradiation at $6 \mathrm{~Gy}$, and a combination of both, the cells were harvested after 48 and $72 \mathrm{~h}$ of incubation and fixed with glutaraldehyde. The fixed cells were then stained with Höchst 33342 solution and cellular morphology was observed under a fluorescence microscope in order to determine the percentage of apoptotic cells. At 48 and $72 \mathrm{~h}$ after treatment with $\mathrm{AMROH}$ alone, the incidence of apoptosis was $0.9 \%$ and $0.88 \%$, respectively, while it was $1.2 \%$ and $0.71 \%$, respectively for $\mathrm{X}$-ray irradiation alone, and $1.4 \%$ and $1.5 \%$, respectively for the combination therapy.

Effects on necrosis induction. As in the case with apoptosis, the radio-enhancement effects of AMROH on A549 cells were investigated in regard to the induction of necrosis, as shown in Fig. 6. The incidence of necrotic cells following AMROH treatment, X-ray irradiation, and a combination of both was investigated using $\mathrm{AO} / \mathrm{EB}$ double staining at 48 and $72 \mathrm{~h}$ after treatment. The incidence of necrosis at 48 and $72 \mathrm{~h}$ after treatment with AMROH alone was $2.4 \%$ and $4.3 \%$, respectively, while it was $2.6 \%$ and $3.66 \%$, respectively, following X-rays alone, and $5.0 \%$ and $6.0 \%$, respectively after combined treatment (Fig. 6). 


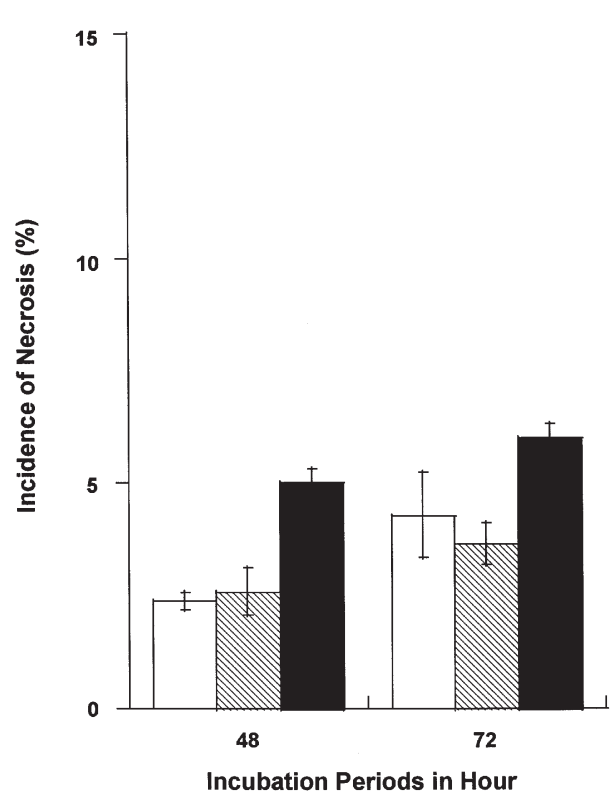

Figure 6. Kinetics of necrosis induction after 48 and $72 \mathrm{~h}$ of incubation following exposure to AMROH, X-ray irradiation, and a combination of both. At the indicated times, A549 cells were double stained with AO/EB and observed under a fluorescence microscope. Rubious cells were counted as necrotic cells. Ordinate: ratio of necrosis for total cells. Abscissa: hours of incubation at $37^{\circ} \mathrm{C}$ following treatment. Columns represent AMROH $(0.02 \mu \mathrm{g} /$ $\mathrm{ml}$ ) for $4 \mathrm{~h}$, irradiation at $6 \mathrm{~Gy}$, and combined treatment in order from the left. The incidence of necrosis following treatment with AMROH or irradiation alone was slightly induced after 48 and $72 \mathrm{~h}$. With the combined treatment, the frequency of necrosis was increased below the additive.

\section{Discussion}

In the present study, the radio-enhancement effects of the topoisomerase II inhibitor AMR and its metabolite AMROH toward the mechanisms of modification in human lung adenocarcinoma A549 cells were investigated.

Profile of $A M R$. The anthracycline derivative AMR and its active metabolite AMROH are synthesized antitumor agents and have been shown to be DNA topoisomerase II inhibitors $(5,6)$. It has been reported that DNA topoisomerase II is vital for essential biological reactions, such as replication, transcription, and genetic recombination $(45,46)$, and Nelson et al reported that mAMSA [4'-(9-acridinylamino) methane sulfonm-anisidide], an antitumor agent, inhibited topoisomerase II in mammals (47). Therefore, topoisomerase II inhibitors are effective anticancer agents, because topoisomerase II inactivation and inhibition have severe effects on cell survival $(48,49)$.

Effects on radiation. Following X-ray irradiation alone, the A549 cells were found to be radioresistant with a $D_{0}$ value of 12 Gy, as shown in Figs. 1 and 2. When the cells were treated with AMR or AMROH prior to irradiation in vitro, the SLDR seen during the early stages after irradiation was inhibited. The so-called shoulder-shape portion from irradiation mainly was diminished by sequential combined treatment with AMR or AMROH, as both AMR and AMROH enhanced radiosensitivity in an additive manner (Figs. 1 and 2). The dose required to achieve $10 \%$ survival (surviving fraction at 0.1 ) with irradiation alone was approximately $8 \mathrm{~Gy}$, while that with the combination therapy was approximately $2 \mathrm{~Gy}$. Comparable results were obtained with approximately one-fourth of the dose by combining radiotherapy with AMR or AMROH, which is a beneficial finding for multidisciplinary anticancer therapy.

We previously investigated the abilities of various chemicals, including adriamycin (doxorubicin), bleomycin, cisplatin, and AMR (or AMROH) to modify the effects of hyperthermia using different cells at kinetic and molecular levels $(23,50-53)$. The effects of AMR, AMROH, ADM (54), and VP-16 (55), which target DNA metabolism, on the radiosensitivity of A549 cells are compared in Table I. When A549 cells were treated with isotoxic doses of AMR, AMROH, ADM or VP-16 for $3 \mathrm{~h}$ and then sequentially subjected to ionizing radiation of 2-8 Gy, comparable degrees of enhancement were noted. These findings clarify that all topoisomerase II inhibitors increase the radiosensitivity of A549 cells. Among the different types of radiotherapy that target the DNA of oncogenes, radiochemotherapy has a direct enhancement effect, because DNA damage increases synergistically in situations in which the drugs and X-ray irradiation simultaneously act on DNA.

Fractionated radiotherapy. Combined radiotherapy with AMR or AMROH from 1 to 4 times the level of fractionated irradiation of 2 Gy for 24-h intervals using A549 cells in vitro was carried out, as shown in Figs. 3 and 4. As a result, the radiosensitivity of sequential combined treatment with AMR or AMROH was enhanced by reducing SLDR for intervals with fractionated irradiation with X-rays alone and the survival curve became parallel with that of continuous irradiation. Namely, when the cells were treated with AMR or AMROH prior to fractionated irradiation, the cytocidal effect at $8 \mathrm{~Gy}$ on the survival curve was approximately 30 times greater than that with irradiation alone. In radiotherapy, if the curative dose exceeds the tolerated dose of normal tissue, irradiation cannot be given without side effects in normal tissue.

However, if it is possible to reduce the radiosensitivity of normal tissue or to increase the radiosensitivity of the tumor, radiotherapy can be performed with reduced side effects. It is generally known that if drugs are used to inhibit the activities of enzyme or the repair of DNA damage, the cells experience interphase cell death without cell division or mitotic cell death after several divisions. When irradiated tumor cells have repaired the damage, the radio-enhancement effects are likely to lead to greater damage with chemotherapy drugs or the repair is inhibited. We found that AMR and AMROH were able to reduce SLDR, thus they are expected to significantly increase the radio-enhancement effects of fractionated irradiation. In the present study, we found that AMR was a candidate anticancer therapeutic agent for non-small cancer cells, as the radio-enhancement effects of AMR were shown from a kinetics point of view.

Induction of apoptosis and necrosis. We also investigated the kinetics of apoptosis during the induction periods following AMROH administration, X-ray irradiation and a combination of both. The induction of apoptosis following irradiation of 6 Gy with $0.02 \mu \mathrm{g} / \mathrm{ml}$ of AMROH for $4 \mathrm{~h}$ increased slightly with time, though there was no significant increase following 
such sequential combination therapy. The induction of necrosis following radiotherapy also increased with time and there was a significant increase in the induction of necrosis after $4 \mathrm{~h}$ of exposure to AMROH followed by X-ray irradiation. The p53-mediated apoptosis has been thought to be cell cycle dependent $(24,56)$. We have reported that a cell phase response of A549 cells with wtp53 to AMR or AMROH was not seen regardless of the agent concentrations (13). Those findings suggested that AMR and AMROH directly inhibit DNA topoisomerase II activities without affecting the p53 cascade, in spite of the wild type. AMR and AMROH were also shown to dynamically enhance the radiosensitivity of A549 cells. Thus, for multidisciplinary anticancer therapy, the antitumor effects of radiotherapy can be improved by administering AMR or its metabolite AMROH.

\section{Acknowledgments}

The present work was supported in part by Grant-in Aid of the Ministry of Education, Science and Culture, Japan, for Scientific Research (C)-2, No. 16591196, (Mechanism of radio-enhancement effect by topoisomerase II inhibitor in human lung carcinoma cells) 2004-2006.

\section{References}

1. Noguchi T, Ichii S, Morisada S, Yamaoka T and Yanagi Y: In vivo efficacy and tumor-selective metabolism of amrubicin to its active metabolite. Jpn J Cancer Res 89: 1055-1060, 1998.

2. Noguchi T, Ichii S, Morisada S, Yamaoka T and Yanagi Y: Tumor-selective distribution of an active metabolite of the 9aminoanthracycline amrubicin. Jpn J Cancer Res 89: 1061-1066, 1998.

3. Hanada M, Mizuno S, Fukushima A, Saito Y, Noguchi T and Yamaoka T: A new antitumor agent amrubicin induces cell growth inhibition by stabilizing topoisomerase II - DNA complex. Jpn J Cancer Res 89: 1229-1238, 1998.

4. Yamauchi S, Kudoh S, Kimura T, Hirata K and Yoshikawa J: Additive effects of amrubicin with cisplatin on human lung cancer cell lines. Osaka City Med J 48: 69-76, 2002.

5. Ogawa M: Novel anticancer drugs in Japan. J Cancer Res Clin Oncol 125: 134-140, 1999.

6. Yamaoka T, Hanada M, Ichii S, Morisada S, Noguchi T and Yanagi Y: Cytotoxicity of amrubicin, a novel 9-aminoanthracycline, and its active metabolite amrubicinol on human tumor cells. Jpn J Cancer Res 89: 1067-1073, 1998.

7. Morisada S, Yanagi Y, Noguchi T, Kashiwazaki Y and Fukui M: Antitumor activities of a novel 9-aminoanthracycline (SM-5887) against mouse experimental tumors and human tumor xenografts. Jpn J Cancer Res 80: 69-76, 1989.

8. Evans HH, Ricanati M, Horng MF and Mencl J: Relationship between topoisomerase II and radiosensitivity in mouse L5178Y lymphoma strains. Mutat Res 217: 53-63, 1989.

9. Coco-Martin JM, Smeets MF, Poggensee M, et al: Use of fluorescence in situ hybridization to measure chromosome aberrations as a predictor of radiosensitivity in human tumour cells. Int J Radiat Biol 66: 297-307, 1994.

10. Guo WF, Lin RX, Huang J, et al: Identification of differentially expressed genes contributing to radioresistance in lung cancer cells using microarray analysis. Radiat Res 164: 27-35, 2005.

11. Harari PM, Fuller DJ, Carper SW, Croghan MK, Meyskens FL Jr, Shimm DS and Gerner EW: Polyamine biosynthesis inhibitors combined with systemic hyperthermia in cancer therapy. Int $\mathrm{J}$ Radiat Oncol Biol Phys 19: 89-96, 1990.

12. Armour EP, McEachern D, Wang Z, Corry PM and Martinez A: Sensitivity of human cells to mild hyperthermia. Cancer Res 53: 2740-2744, 1993.

13. Hayashi S, Hatashita M, Matsumoto H, Jin ZH, Shioura H and Kano E: Modification of thermosensitivity by amrubicin or amrubicinol in human lung adenocarcinoma A549 cells and the kinetics of apoptosis and necrosis induction. Int J Mol Med 16: 381-387, 2005.
14. Valenzuela DM and Groffen J: Four human carcinoma cell lines with novel mutations in position 12 of c-K-ras oncogene. Nucleic Acids Res 14: 843-852, 1986.

15. Lehman TA, Bennett WP, Metcalf RA, et al: p53 mutations, ras mutations, and p53-heat shock 70 protein complexes in human lung carcinoma cell lines. Cancer Res 51: 4090-4096, 1991.

16. Noble JR, Willetts KE, Mercer WE and Reddel RR: Effects of exogenous wild-type p53 on a human lung carcinoma cell line with endogenous wild-type p53. Exp Cell Res 203: 297-304, 1992.

17. Yonish-Rouach E, Resnitzky D, Lotem J, Sachs L, Kimchi A and Oren M: Wild-type p53 induces apoptosis of myeloid leukaemic cells that is inhibited by interleukin-6. Nature 352 : 345-347, 1991.

18. Shaw P, Bovey R, Tardy S, et al: Induction of apoptosis by wild-type p53 in a human colon tumor-derived cell line. Proc Natl Acad Sci USA 89: 4495-4499, 1992.

19. Martinez J, Georgoff I, Martinez J and Levine AJ: Cellular localization and cell cycle regulation by a temperature-sensitive p53 protein. Genes Dev 5: 151-159, 1991.

20. Kuerbitz SJ, Plunkett BS, Walsh WV and Kastan MB: Wildtype p53 is a cell cycle checkpoint determinant following irradiation. Proc Natl Acad Sci USA 89: 7491-7495, 1992.

21. Sionov RV and Haupt Y: The cellular response to p53: the decision between life and death. Oncogene 18: 6145-6157, 1999.

22. Vousden KH: p53: death star. Cell 103: 691-694, 2000.

23. Hayashi S, Kano E, Tsuji K, Furukawa-Furuya M, Yoshikawa S, Hatashita M, Matsumoto H, Jin ZH, Ohtsubo T and Kitai R: Modification of thermosensitivity and chemosensitivity induced by combined treatments with hyperthermia and adriamycin. Int J Mol Med 8: 417-422, 2001.

24. Yonish-Rouach E, Grunwald D, Wilder S, Kimchi A, May E, Lawrence JJ, May P and Oren M: p53-mediated cell death: Relationship to cell cycle control. Mol Cell Biol 13: 1415-1423, 1993.

25. Hayashi S, Kano E, Matsumoto H, Hatashita M, Ohtsubo T, Nishida T, Shioura H and Kitai R: Thermosensitivity, incidence of apoptosis and accumulations of hsp72 and p53 proteins of murine L cells in wild type status of p53 gene. J Exp Clin Cancer Res 18: 181-189, 1999.

26. Ogawa $\mathrm{Y}$, Nishioka $\mathrm{A}$, Inomata $\mathrm{T}$, et al: Ionizing radiationinduced apoptosis in human lymphoma cell lines differing in p53 status. Int J Mol Med 5: 139-143, 2000.

27. Lowy DR and Willumsen BM: Function and regulation of ras. Annu Rev Biochem 62: 851-891, 1993.

28. Kaziro Y, Itoh H, Kozasa T, Nakafuku M and Satoh T: Structure and function of signal-transducing GTP-binding proteins. Annu Rev Biochem 60: 349-400, 1991.

29. McBride OW, Swan DC, Tronick SR, Gol R, Klimanis D, Moore DE and Aaronson SA: Regional chromosomal localization of N-ras, K-ras-1, K-ras-2 and myb oncogenes in human cells. Nucleic Acids Res 11: 8221-8236, 1983.

30. Elkind MM and Sutton H: X-ray damage and recovery in mammalian cells in culture. Nature 184: 1293-1295, 1959.

31. Elkind MM, Sutton-Gilbert H, Moses WB, Alescio T and Swain RW: Radiation response of mammalian cells grown in culture. V. Temperature dependence of the repair of X-ray damage in surviving cells (aerobic and hypoxic). Radiat Res 25 : 359-376, 1965.

32. Marchese MJ, Zaider $M$ and Hall EJ: Dose-rate effects in normal and malignant cells of human origin. Br J Radiol 60: 573-576, 1987.

33. Matthews JH, Meeker BE and Chapman JD: Response of human tumor cell lines in vitro to fractionated irradiation. Int $\mathbf{J}$ Radiat Oncol Biol Phys 16: 133-138, 1989.

34. Cummings J and Smyth JF: DNA topoisomerase I and II as targets for rational design of new anticancer drugs. Ann Oncol 4: 533-543, 1993.

35. Tewey KM, Rowe TC, Yang L, Halligan BD and Liu LF: Adriamycin-induced DNA damage mediated by mammalian DNA topoisomerase II. Science 226: 466-468, 1984.

36. Hill BT, Whelan RD, Hosking LK, et al: A lack of detectable modification of topoisomerase II activity in a series of human tumor cell lines expressing only low levels of etoposide resistance. Int J Cancer 47: 899-902, 1991.

37. Lock RB and Hill BT: Differential patterns of anti-tumour drug responses and mechanisms of resistance in a series of independently-derived VP-16-resistant human tumour cell lines. Int J Cancer 42: 373-381, 1988. 
38. Kerr JF, Wyllie AH and Currie AR: Apoptosis; a basic biological phenomenon with wide-ranging implications in tissue kinetics. Br J Cancer 26: 239-257, 1972.

39. Khodarev NN, Sokolova IA and Vaughan AT: Mechanisms of induction of apoptotic DNA fragmentation. Int J Radiat Biol 73: 455-467, 1998.

40. Allan DJ and Harmon BV: The morphologic categorization of cell death induced by mild hyperthermia and comparison with death induced by ionizing radiation and cytotoxic drugs. Scanning Electron Microsc: 1121-1133, 1986.

41. Cho KS, Lee EH, Choi JS and Joo CK: Reactive oxygen speciesinduced apoptosis and necrosis in bovine corneal endothelial cells. Invest Ophthalmol Vis Sci 40: 911-919, 1999.

42. Giard DJ, Aaronson SA, Todaro GJ, Arnstein P, Kersey JH, Dosik $\mathrm{H}$ and Parks WP: In vitro cultivation of human tumors: establishment of cell lines derived from a series of solid tumors. J Natl Cancer Inst 51: 1417-1423, 1973.

43. Lieber M, Smith B, Szakal A, Nelson-Rees W and Todaro G: A continuous tumor-cell line from a human lung carcinoma with properties of type II alveolar epithelial cells. Int J Cancer 17: 62-70, 1976.

44. Leite M, Quinta-Costa M, Leite PS and Guimaraes JE: Critical evaluation of techniques to detect and measure cell death-study in a model of UV radiation of the leukaemic cell line HL60. Anal Cell Pathol 19: 139-151, 1999.

45. Wang JC: Recent studies of DNA topoisomerases. Biochim Biophys Acta 909: 1-9, 1987.

46. Kelly TJ: SV40 DNA replication. J Biol Chem 263: 17889-17892, 1988.

47. Nelson EM, Tewey KM and Liu LF: Mechanism of antitumor drug action: poisoning of mammalian DNA topoisomerase II on DNA by 4'-(9-acridinylamino)-methanesulfon-m-anisidide. Proc Natl Acad Sci USA 81: 1361-1365, 1984.
48. Liu LF: DNA topoisomerase poisons as antitumor drugs. Annu Rev Biochem 58: 351-375, 1989.

49. Kampinga $\mathrm{HH}$ : Hyperthermia, thermotolerance and topoisomerase II inhibitors. Br J Cancer 72: 333-338, 1995.

50. Ohtsubo T, Kano E, Ueda K, Matsumoto H, Saito T, Hayashi S, Hatashita M, Jin Z and Saito H: Enhancement of heat-induced heat shock protein (hsp)72 accumulation by doxorubicin (Dox) in vitro. Cancer Lett 159: 49-55, 2000.

51. Ohtsubo T, Saito H, Matsumoto H, Hayashi S, Shioura H, Kitai R, Saito T and Kano E: In vitro effects of hyperthermia combined with cisplatin or peplomycin on the human maxillary carcinoma cell line IMC-2. Int J Hyperthermia 13: 59-67, 1997.

52. Shioura H, Hayashi S, Matsumoto H, Kitai R, Ohtsubo T, Nishida T, Zhang SW, Yoshida M, Ishii Y and Kano E: The effects of combined treatments with low hyperthermia and bleomycin on survivals of murine L cells. J Exp Clin Cancer Res 16: 147-152, 1997.

53. Matsumoto H, Hayashi S, Shioura H, Ohtsubo T, Nishida T, Kitai R, Ohnishi T and Kano E: Suppression of heat-induced p53 accumulation and activation by CDDP or X-rays in human glioblastoma cells. Int J Oncol 13: 741-747, 1998.

54. Arcamone F, Franceschi G, Penco S and Selva A: Adriamycin (14-hydroxydaunomycin), a novel antitumor antibiotic. Tetrahedron Lett 13: 1007-1010, 1969.

55. Gensler WJ and Gatsonis CD: The podophyllotoxinpicropodophyllin equilibrium. J Org Chem 31: 3224-3227, 1966.

56. Ryan JJ, Danish R, Gottlieb CA and Clarke MF: Cell cycle analysis of p53-induced cell death in murine erythroleukemia cells. Mol Cell Biol 13: 711-719, 1993. 